Доц. д-р Лазар Јовевски

Универзитет „Св. Кирил и Методиј“

Правен факултет „Јустинијан Први““, Скопје

\title{
ИНКЛУЗИВЕН ПАЗАР НА ТРУД
}

UDK: $316.344 .7: 331.5(497.7)$

\section{Апстракт}

Основен проблем на кој се задржува овој труд е капацитетот и можностите на македонскиот пазар на труд за вклучување на ранливите и маргинализирани групи на граѓани кои бараат работа. Во таа смисла трудот ги опфаќа реалните политики кои се спроведуваат во насока на интеграција на ранливите групи, како лицата со инвалидитет, самохраните родители, жените жртви на семејно насилство и други, преку нивно вработување. На тој начин се анализираат ефектите на трудовата интеграција и нејзините ефекти во пошироката општествена интеграција на овие ранливи групи. Во трудот се дава јасна слика за нормативната рамка која го регулира ова прашање, нејзините добри и лоши страни, како и потребите за подобрување и развивање на инклузивен пазар на труд во Македонија, кој ќе се темели на принципите на недискриминација и социјална правда. Во истражувањето јасно се согледуваат рамковните можности на македонскиот пазар на труд и неговиот апсорпционен капацитет воопшто, понатаму вклученоста на маргинализираните групи на граѓани во трудот, значењето на нивното вклучување во трудот, односно вработувањето и пошироките општествени ефекти.

Методолошки во трудот се прави комбинација на емпириските показатели со аналитичко-синтетичкиот метод, преку активно 
Ревија за сочијална политика, год. 8, бр.11/2 Скопје, ноември 2015

користење на правно-компаративната методологија која има за цел продлабочено разбирање на институтите кои се предмет на анализа.

Во трудот се констатира и издвојува значењето и улогата на инклузивноста на пазарот на труд за ранливите групи на граѓани, како систем преку кој се овозможува најбрза и најефикасна поширока нивна општетсвена интеграција.

Клучни зборови: пазар на труд, ранливи групи, инклузија, социјална интеграција.

\title{
Inclusive Labor Market
}

\begin{abstract}
A major problem that point out this paper is capacity and capabilities of Macedonian labor market inclusion of vulnerable and marginalized groups of people looking for work. In that sense, the paper covers the actual policies implemented in the context of integration of vulnerable groups, such as persons with disabilities, single parents, women victims of domestic violence and others, through their employment. Thus analyze the effects of labor integration and its effects on the wider social integration of vulnerable groups. This paper gives a clear picture of the legal framework that governs the issue, its good and bad sides, and needs for improvement and development of inclusive labor market in Macedonia, which will be based on the principles of non-discrimination and social justice. The research clearly perceived opportunities of the Macedonian labor market and its absorption capacity in general, further involment of marginalized groups of citizens, the importance of their involvement in labor or employment and wider societies effects. This paper combines the empirical performance an alytical-synthetic method, by using comparative legal methodology that aims in deeph understanding of institutes that are subject to analysis. The paper concludes the role of the inclusiveness of the labor market for vulnerable groups, as a system that allows the fastest and most efficient social their wider integration.
\end{abstract}


Keywords: labor market; vulnerable groups; inclusion; Social integration.

\section{1. Поим и дефиниција}

Инклузија (лат. Inclusion) потекнува од латинскиот збор includere што значи вклучување, да се вклучи, опфаќање, да се содржи, подразбирање (И. Клајн и М. Шипка, 2008:519). Овој термин се среќава како литературна техника уште во староеврејската мисла, преточена пред сѐ во Стариот Завет (Тора), како и во Новиот Завет каде е познат како концентричен принцип или структура плик, кој се состои во создавање на рамка преку ставање на сличен материјал на почетокот и крајот, кои меѓусебе се поврзани и прават една целина, се надополнуваат (види исто:http://en.wikipedia.org/wiki/Incl-usio).

Во правна смисла под инклузија се подразбира правила на интерпретација, толкување и примена преку кои во државата се вклучува и опфаќа нешто што е предходно исклучено (W.J. Stewart, R. Burgess 1999:202). Овде акцентот како што може да се забележи се става на државата, но би можеле да се сложиме дека оваа дефиниција се однесува пошироко и го опфаќа целокупното општество.

Инклузијата има повеќе сегменти и делови преку кои можеме да ја разгледуваме. Во последните години актуелно е прашањето на создавање на инклузивен образовен систем кој концепциски и методолошки е поинаков од „класичниот“ модел на образование. Од друга страна пак инклузијата најчесто се поврзува со лицата со инвалидитет, иако како поим има пошироко значење и може да се однесува на различни категории вработени кои се исклучени, односно маргинализирани заради различни причини и по различни основи.

Тоа на што ние посебно ќе се задржиме во оваа прилика е дали постои и што е тоа инклузивен пазар на труд, дали тој е потребен и кои се неговите предности и недостатоци. Значи, инклузијата ја 
Ревија за соиијална политика, год. 8, бр.11/2 Скопје, ноември 2015

разгледуваме пред сѐ од трудово-правен аспект, содржински канализирана преку пазарот на труд. Зошто пазар на труд?

Па пред сѐ затоа што пазарот на трудот е полето каде се одвива основната пазарна (капиталистичка) функција на модерниот економски систем, а тоа е среќавање на понудата и побарувачката на работната сила. Исто така, пазарот на труд може и треба да го разгледуваме како ефикасен инструмент преку кој се овозможува трудово-правна инклузија на исклучените граѓани во општеството и на крајот преку пазарот на трудот секако се одвива економската инклузија на граѓаните.

Оттука инклузијата во трудово-правна смисла може да ја дефинираме како мерки и стратегии кои се преземаат за рефокусирање на трудовите приоритети во насока за создавање на работни места кои ќе ги вклучат невработените кои се искучени или тешко можат да се вклучат на пазарот на труд. Ова претставува процес кој има за цел создавње на нови работни места преку принципот на пристојна работа и, т.н. зелени работни места, како и анимирање на севкупната општествена јавност, а особено компаниите (M. Morising 2005:26) за содавање на свест во духот на еднаквост, солидарност и општествена одговорност.

Ова сфаќање на инклузивниот пазар на труд во последните две децении е особено актуелно во Европската унија и е дел од принципите на Лисабон. Всушност ова претставува основната модерна европска парадигма која има за цел да изврши ремоделирање на системот, но и на вредностите на, т.н. „нов светски поредок“ (сфатен во економска смисла), кој меѓу другото главната реформа ќе ја насочи, (а тоа веќе и се случува) токму кај пазарот на труд. Новите глобални вредности имаат за цел да промовираат глобални принципи кои се дел од „општиот“ пазар на труд, кој пак од друга страна се чини афирмира коорпоративни вредности и нееднаквост во прераспределбата на приходите. Затоа треба да бидеме внимателни во разбирањето, или поточно толкувањето на идејата за глобален инклузивен пазар на труд кој во себе ги вклучува 
флексибилноста на трудот, од една страна, и сигурноста како нејзин коректив.

Сметаме дека без вклучување на изворни есхатолошки принципи во идејата за глобален , или помалку „европски“ инклузивен пазар на труд ќе тргнеме по пат кој нема да не доведе до вистината и правилното разбирање на инклузијата и инклузивниот пазар на труд кој треба да извира од богочовечката природа на личноста на човекот и принципите на еднаквост, почитување, рамноправност и взаемно уважување кои може да се сублимираат во заповеда „да се љуби ближниот како себеси“ (спореди: Матеј, 22:39,40 2010:62).

\section{2. Опфат на лица}

Инклузивниот пазар на труд има две основни димензии. Тоа е општесвено-просторна, која е објективна, и субјективно-временска, која е субјективна. Објективноста се огледа во тоа што треба да постојат одредени објективни предуслови, или можеме да кажеме претпоставки, за да има потреба од инклузивен пазар на труд. Оваа димензија, исто така, подразбира дека инклузивниот пазар на труд може да постои само во општествени рамки кај веќе постоечка општествено-економска формација која најчесто е капитализам (пазарна економија). Оваа карактеристика на инклузивниот пазар на труд е константна и не зависи од одредени субјективни карактеристики на невработените, или пак веќе вработените.

Од друга страна, инклузивниот пазар на труд подразбира дека тој има конкретен опфат на лица кои се маргинализирани, односно исклучени целосно или делумно од пазарот на труд, или пак постојат конкретни пречки кои можат да бидат и од објективен карактер (на пр. законски одредби) за вработување на овие лица. Оваа димензија е најчесто променлива и варира од држава до држава, а во зависност од економските, правните и духовните „перформанси“ на општеството. 
Ревија за соиијална политика, год. 8, бр.11/2 Скопје, ноември 2015

Инклузивниот пазар на труд нејчесто ги опфаќа лицата со инвалидитет, самохраните родители, децата без родители, зависниците од дроги, болните од хронични болести, во одредени случаи жените, лицата по завршување на казна затвор, лицата со минимално или без образование, малолетниците, постарите работници, неквалификуваните лица и други.

Опфатот на лица е во директна зависност со социјалната економија, односно со финасиските можности на општеството. Всушност, квалитетот на инклузивниот пазар на труд во голема мера е детерминиран од финасиските вложувања кои подразбираат директни владини финасиски интервенции на пазарот на труд или пак финсиски инвестиции од страна на стопанските субјекти. Секако, можен е и комбиниран систем на финсиско вложување, а со цел квантитативно и квалитативно вклучување на маргинализираните граѓани на пазарот на труд во центарот на трудот, или поинаку кажано, нивно вработување (пред сѐ од аспект на неопределно време).

Од друга страна пак кога говориме за тоа кои лица треба да се вклучат на пазарот на труд, несомнено е дека ќе мора да конкретизираме по однос на категории на невработени и тоа пред сѐ заради субјективните карактеристики кои претставуваат пречка за влегување на пазарот на труд и конкретно вработување. Тоа значи дека инклузивноста подразбира конкретизација на мерки и активности насочени кон точно определена група на невработени, а со цел нивно вклучување во пазарот на труд. Па така се говори за инклузивност на лицата со инвалидитет, на самохраните мајки, инклузивност на пазарот на труд на бившите затвореници итн., па дури можно е во одредени категории на невработени да постојат и одредени подгрупи. 


\section{3. Новите принципи на инклузивниот пазар на труд}

Концептот на инклузивната стратегија на пазарот на труд е клучна за постигнување на вклученост на ранливите групи во трудот, подржано од владините политики и политиките на претставување (D. Etherington 2012:30-34). Улогата на државата е особено битна од аспект на креирање на политиката на инклузивен пазар на труд. Таа преку своите инструменти пред сѐ од нормативен аспект ја обликува стратегијата. Од друга страна, инклузивноста на пазрот на труд подразбира вклучување на мерки кои значат заштита на здравјето и безбедноста на работното место, а сфатени како дел од концептот на достоинствена работа. Исто така, како основен принцип на инклузивноста на пазарот на труд треба да ја издвоиме флексибилизацијата на работните места (flex-jobs), но истовремено поткрепени со сигурноста на работните места преточени во синтагмата флексигурност на работни места (Т.Каламатиеви А.Ристевски 2013:81-83). Зошто ова е потребно и што значи тоа?

Пред сѐ од аспект на проодност на маргинализираните лица на пазарот на труд потребно е создавање на услови кои ќе овозможуваат полесно влегување на пазарот на труд и негово полесно напуштање. Оваа флексибилност е основа за да можеме да говориме за инклузивност на пазарот на труд. Од друга страна, флексибилизацијата на пазарот на труд не смее да биде аргумент за екстремна флексибилизација која би значела намалување на платите, правна несигурност и намалување на правата на работниците, на сметка на барањето за зголемена и ефикасна продуктивност во трудот (A. Bronstein 2009).

Глобалната економска криза и новите глобални предизвици делуваат стимулативно на флексибилизацијата на пазарот на труд. Така во време на глобална економска криза и хронична невработеност се смета дека пазарите ќе претставуваат „темпирана бомба““ во однос на неколку прашања: демографското намалување, предизвикано од падот на наталитетот, а не е исклучен и проблемот од недостиг на квалификувани работници (B.Noteboom 2013).Можеби најзначаен фактор околу кој ќе се формираат новите 
Ревија за соиијална политика, год. 8, бр.11/2 Скопје, ноември 2015

принципи на инклузивниот пазар на труд е стареењето на населението наспроти новородените деца, кое ќе предизвика бура на промени кои веќе се случуваат и се однесуваат на покачување на старосната граница за пензионирање. Ова ќе влијае силно на отворање на пазарите на труд и суштински менување на основните принципи на структурата на работниот однос. Клучно прашање во тој правец ќе биде пензиската реформа.

\section{4. Структура на инклузивниот пазар на труд}

Пазарот на труд за да може да се каже дека е инклузивен потребно е во себе да инкорпорира неколку компоненти. Постојат три основни и општи компоненти кои ја детерминираат инклузивноста на пазарите на труд. Тоа се правната рамка, професионалната орентација, рехабилитација и адаптација, како и свеста и одговорноста.

\section{a. Правна рамка}

Правната рамка е основната нормативна компонента преку која се уредува, обликува, односно нормира системот на инклузивност. Оваа компонента е многу важна и без неа не може да стане збор, воопшто, за постоење на инклузивен пазар на труд. Значи, од правните одредби и уредувањето на односите на пазарот на трудот започнува сѐ. Инклузивноста, како и самиот степен на инклузивноста на пазарот на труд се определува преку одредбите кои ја регулираат оваа област, а тоа најчесто се законите за работни односи (во Република Македонија тоа е Законот за работни односи, (види Сл.в. на PM бр.62/05), посебните закони кои се однесуваат на конкретни групи граѓани како што се законите за вработување на лица со инвалидитет, понатаму, законските решенија кои се однесуваат на прашањата на невработеност како и за правното уредување на агенциите кои посредуваат на пазарот на труд, како што тоа во Македонија е Агенцијата за вработување и посебните агенции за привремени вработувања (во Република Македонија постојат посебни закони кои ја уредуваат работата и надлежностите на 150 
Агенцијата за вработување на РМ, од една страна, и посебните агенции за привремени вработувања, види Сл. в. на РМ бр.112/14 и Сл. в. на РМ бр.49/06 и понатаму).

Законската рамка треба да овозможи флексибилност и отвореност на пазарот на труд преку што полесно ќе се влегува на пазарот на труд и полесно ќе се излегува. За оваа динамика потребно е покрај соодветна законска рамка да постојат и економски претпоставки, односно потреба за работна сила на пазарот на труд, воопшто. Па така колку потребата е поголема и самата флексибилност добива на интензитет, или поинаку кажано, полесно се наоѓ работа, па полесно вработените се одлучуваат да ја сменат веќе постоечката работа, или пак да одбијат понуда за работа барајќи поповолна. Во спротивно, пазарот на труд доколку е слабо абсорбитилен, тој станува покрут и во однос и на инклузивноста. Во таков случај нормативната рамка мора да биде повеќе екстензивна и да предвидува поголем број на мерки и чекори за да се постигне задоволително ниво на инклузивност. Со други зборови на законските одреби влијаат надворешните (економски или пошироко општествени) фактори, но и законските решенија ја обликуваат инклузивноста на пазарот на труд. Одовде, на крајот на денот ќе дојдеме до заклучок дека законската рамка зависи од социјалната политика во земјата која се однесува на трудовите и социјалните прашања (Н. Ружин 2004; J. Baldock, L. Milton, N. Manningu S. Vickerstaff 2012).

\section{б) Професионална ориентација, рехабилитација и адаптација}

Професионалната ориентација претставува важна компонента на системот на инклузивност на пазарот на труд. Таа подразбира компатибилност на образовниот систем во однос на пазарот на труд. Образовниот систем треба да биде така поставен со наставни програми и оспособување и усовршување на лицата за да тие подоцна можат активно да се вклучат на пазарот на труд, согласно неговите потреби. Тоа значи развивање на образовна политика која ќе биде компонената на социјалната политика. Образовниот систем треба да се моделира во насока да по завршување на школувањето, 
Ревија за соиијална политика, год. 8, бр.11/2 Скопје, ноември 2015

усовршеното лице во одредена област може да биде конкурентно на пазарот на труд и релативно лесно да наоѓa вработување. Оваа заадача не е едноставна ниту пак лесна и истата подразбира константно преиспитување и развивање на моделот на образование, согласно потребите на пазарот на труд и стопанството во една земја. Сметаме дека оваа компонента е многу важна, особено од аспект на ранливите категории граѓани на пазарот на труд како што се лицата со инвалидитет, самохраните родители, долгорочно невработените, младите невработени итн. Одреден број на земји како што се Германија, Франција, Скандинавските земји, па и Грција на ова прашање посветуваат големо внимание и образовниот систем го проектираат и развиваат токму во насока на потребите на пазарот на труд. За тоа потребно е да се направат поголем број на анализи и проекции што е краткорочно потребно како квалификација на пазарот на труд, а што долгорочно, и во која насока ќе се развива стопанството.

Се чини во македонски рамки не се посветува доволно внимание на ова прашање и истото претставува проблем кој подолго време го обременува македонскиот пазар на труд, како и целото стопанство. Сметаме дека во иднина ќе треба да се направи сериозна анализа кои стопански и нестопански гранки ќе се развиваат, кои се потребите на пазарот на труд и соодветно на тоа да се развива и македонскиот образовен систем почнувајќ́ од основното, па до виското образование.

Исто така, на инклузивноста на пазарот на труд влијае и неформалното образование кое ја опфаќа едукацијата преку одредени образовни центри или системи кои имаат за цел зголемување на конкурентноста на лицата на пазарот на труд. Исто така, неформалното образование во одредени случаи има за цел да ги корегира и надополни пропустите на формалното образование и на тој начин директно или индиректно да влијае како коректив на флексибилноста на пазарот на труд.

Професионалната ориентација ако ја разгледуваме од аспект на маргинализирани групи на лица кои тешко имаат пристап на 152 
пазарот на труд, истата добива поголемо значење. Притоа системот на неформално образование во македонски рамки има значајна улога во инклузивноста на пазарот на труд токму за овие лица, од една страна, како и со промоција и развивање на концептот на „доживотно учење“, од друга страна.

Инклузивноста на пазарот на труд за лицата со инвалидитет подразбира и воспоставување на систем на професионална рехабилитација кој меѓу другото опфаќа мерки за прекфалификација и доквалификација на овие лица. Исто така, инклузивноста на пазарот на труд во поширока смисла значи и создавање на одредени општи и посебни работни услови и адаптација на работните места, согласно можностите на вработените. Ова особено од аспект на развивање на концептот на ,достојна работа“, што претставува основен двигател во рамките на Меѓународната организација на трудот во последнава декада (МОТ види: веб страна на организацијата).

\section{в) Свест и одговорност}

Се чини оваа компонента на инклузивниот пазар на труд е најтешко достижна, можеби затоа што во себе содржи метаправна компонента која проникнува од моралните и етичко-филозофските вредности на пазарот на труд, како и општеството пошироко. Развивањето на свеста и одговорноста подразбира духовен препород во однос трудот и поинакво гледање на трудово-правните односи. Сепак, она што може конкретно да се ефектуира и преточи во конкретна правна норма, а во насока на созадавање на инклузивен пазар на труд е промовирање на концептот на социјална економија. Тоа подразбира развивање на пазарен економски систем кој во себе длабоко ќе ги инкорпорира социјалните вредности, најнапред преку носење на закон за социјално претприемништво, но и соодветни одредби во останатите закони, пред сѐ во законите за работни односи. Основна цел на ваквиот закон е да нормира односи помеѓу претприемачите, лица кои бараат работа или се веќе вработени и пошироката општествена заедница. Поле на кое се одигрува оваа интеракција е токму пазарот на труд. Исто така, потребно е социјално 
Ревија за соиијална политика, год. 8, бр.11/2 Скопје, ноември 2015

инвестирање преку одредени мерки и програми кои ќе делуваат стимулативно на отвореноста на пазарот на труд и неговата флексибилност. Инвестирањето треба да биде двосостојбно, како од страна на државата, така и преку стопанството. Од друга страна, овие законски измени и новини потребно е да бидат подржани со развивање на коорпоративната социјална одоворност, особено во македонски рамки. Исто така, глобалната економска криза покажа дека токму социјалното претприемништво преку кое се вклучуваат сите субјекти (претприемачите, државата и невработените) за негова реализација и имплементација е едно од средствата за полесно и побрзо надминување на кризата.

Целиот систем на социјална економија и социјално претприемништво како краен резултат треба да испорача практична примена на норми кои предвидуваат мерки за зголемување на инклузивноста на пазарот на труд што би значело подобрување, зголемување и отворање на пазарот на труд како во однос на вработувањето, така и при престанокот на работниот однос, a cè co цел полесно вработување и зголемување на вработеноста. Покрај тоа, оваа практична димензија директно влијае на духовната димензија за сфаќањето на инклузивниот пазар на труд, односно со други зборови развивање на свест и одговорност како од страна на работодавачите, така и од страна, на вработените, но и пошироката општествена заедница, за нужноста од меѓусебна поврзаност и заедничка детерминираност. Всушност, развивањето на одговорноста за другиот до себе и посакувањето на доброто на другиот, би требало да е подлабоко вплетено во свеста на секој поединец кој е дел од пазарот на труд. Токму затоа треба да се каже дека практичните мерки на создавање на систем на социјална економија која подразбира инклузивен пазар на труд влијае на свеста, а со тоа и на одговорноста, но и свесноста креира свои импликации во создавањето на инклузивен пазар на труд и неговата примена. Овој однос е взаемен и меѓусебно се надополнува (тоа е однос vice versa). 


\section{5. Наместо заклучок}

Светот денес се соочува со бројни предизвици кои се од различен аспект, но се чини оние поврзани со вработувањето, одржливиот економски раст и еколошкиот баланс наспроти концептот на индустријализација и автоматизација се клучните точки околу кои ќe се одвива идната глобална дебата и делување. Овие предизвици претпоставуваат постоење и развивање на инклузивен пазар на труд кој ќе дозволува и потикнува вклучување на работоспособното население во трудот и потреба за обезбедување на нивен професионален развој. Вработувањето е основен лајтмотив на инклузивниот пазар на труд, кој треба да овозможи инклузивен одржлив развој, но вработувањето не е доволено само по себе. Доколку постои богата понуда на работна сила, таа треба да биде квалификувана и да одговара на побарувачката на работна сила од страна на работодавачите. Токму затоа инклузивноста го опфаќа образовниот сектор и професионалната ориентација, и не може да зборуваме за инклузивен пазар на труд без соодветна релација со образовниот систем во земјата.

Во стратегијата на Европската комисија 2020 како една од основните цели е изградба на инклузивен пазар на труд. Но, тој пазар треба да биде основан на принципите на социјална правда и преземање на чекори на структурни реформи и социјални инвестиции, пред сѐ во рамките на активно вклучување на маргинализираните категории граѓани на пазарот на труд преку активните мерки на вработување.

Од друга страна, коорпоративната социјална одговорност треба да биде минимумот на вклучување на стопанскиот сектор во концептот на инклузивен пазар на труд. Ова, затоа што потребно е создавање на свест за праведна распределба на ресурсите и приходите како глобално, така и национално.

Во правниот систем, нормативната рамка ќе треба да одговори на предизвикот на создавање прифатлива законска регулатива наспроти потребите на новиот (инклузивен) економски развој, 
Ревија за сочијална политика, год. 8, бр.11/2 Скопје, ноември 2015

земајќи ги предвид односите помеѓу понудата и побарувачката на работна сила. Се чини во иднина ќе биде потребен нов свеж поглед и нова нармативна рамка за системот на пензиско осигурување и осигурување во случај на невработеност, а поставен низ призмата токму на одржување на балансот на вработувањето, наспроти стареењето на населението.

На крајот, можеме да кажеме дека претстои исклучителен период во областа на трудовото право и пазарите на труд, кој како основна мисија ќ ја има „обликување на светот на трудот“ преку создавање на ефикасен и флексибилен, односно инклузивен пазар на труд. 


\section{Литература}

Иван Клајн, Милан Шипка, „Велики решник страних речи и израза“, Прометеј, Нови Сад, IV издање, 2008, стр. 519.

Види: http://en.wikipedia.org/wiki/Inclusio

W.J. Stewart, R. Burgess, “Dictionary of Law”, Unwin Hyman, Glasgow, 1999, p. 202.

Mette Morising, "Inclusive Labour Market Strategies", Corporate Social Responsibility Across Europe, 2005, p. 26.

Спореди: Матеј, 22:39,40, „Новиот Завет“, Библиско здружение на РМ, ревидирано издание, 2010, стр. 62.

David Etherington, "Welfare to work and the inclusive labour market: a comparative study of activation policies for disability and long-term sikness benefit claimant in the UK and Denmark", Journal of European Social Policy, feb. 2012, p. 30-44.

T. Каламатиев, А. Ристевски, „Флексибилност и сигурност радног односа у радном законодавству Републике Македоније (развој и перспектива), часопис за теорију и праксу радног и социјалног права, Београд, 2013, стр. 81-83.

A. Bronstein, International and Comparative Labour Law, Current Challenges, ILO, 2009.

Ben Noteboom, Pour un marche du travail inclusif, Randstand Holding,OCDE, 2013.

Во Република Македонија тоа е Законот за работни односи, Службен весник на РМ. бр. 62/05 и понатаму.

Во Република Македонија постојат посебни закони кои ја уредуваат работата и надлежностите на Агенцијата за вработување на РМ, од една страна, и посебните агенции за привремени вработувања. Види: Закон за вработување и осигурување во случај на невработеност прочистен текст, Службен весник на РМ бр.112/14 и Закон за агенциите за привремени вработувања, Службен весник на РМ бр. 49/06 и понатаму.

Спореди: Н. Ружин, „Социјална политика“, Скопје, 2004, стр.223-251

Џон Балдок, Лавинија Милтон, Ник Менинг Сара Викерстаф, „Социјална политика(издание на македонски)“, Оксфорд, 2012, стр. 103-124

ILO, види: http://www.ilo.org/global/lang--en/index.htm 
